\title{
Middle to late Holocene coastal evolution along the south coast of Upolu Island, Samoa
}

\author{
Ian D. Goodwin ${ }^{\mathrm{a}, *}$, Eric E. Grossman ${ }^{\mathrm{b}, 1}$ \\ a Environmental Geoscience Group, School of Environmental and Life Sciences, University of Newcastle, Callaghan, \\ NSW 2380, Australia \\ b Department of Geology and Geophysics, School of Ocean and Earth Science and Technology, University of Hawaii, \\ 1680 East-West Road, Honolulu, HI 96822, USA
}

Received 10 June 2002; received in revised form 10 July 2003; accepted 18 August 2003

\begin{abstract}
Stratigraphic surveys and sedimentological analyses of coastal sediments and reef cores along the south coast of Upolu Island, Samoa, reveal that during the middle Holocene this coast was characterised by barrier spits, open lagoons, and estuaries. These estuarine systems matured during the late Holocene, with progressive sedimentation and inlet closure, leading to the dominance of mangrove swamps in the past 1000 years. Contemporaneous with the transition of open estuaries to mangrove swamps was the aggradation and progradation of coastal plains. The coastal progradation since $700-1000$ years BP is best explained by increased sediment availability and reduced incident wave energy at the shore resulting from the shallowing and subsequent cessation of reef crest accretion following the midHolocene sea-level highstand ca. $\sim 4500$ yr BP. A small relative sea-level (RSL) lowering since 700-1000 years may have contributed to the positive sediment budget. This study highlights the need for island-wide coastal surveys to assess the relative roles of RSL, sediment budgets, and hydrodynamics on coastal evolution and stability. Differences in coastal evolution around Upolu Island may also be influenced by differential tectonic movements associated with late Holocene volcanism, coseismicity, and/or submarine landslides.
\end{abstract}

(C) 2003 Elsevier B.V. All rights reserved.

Keywords: Late Holocene; coastal evolution; Samoa; carbonate sediments; sea level

\section{Introduction}

The prospect of rising sea level, primarily due to changing steric and eustatic contributions, is a major concern among Pacific Island countries.

\footnotetext{
1 Present address: US Geological Survey, Pacific Science Center, 1156 High Street, Santa Cruz, CA, 95064, USA.

* Corresponding author. Fax: +61-2-4921-6925.

E-mail addresses: ian.goodwin@newcastle.edu.au

(I.D. Goodwin), egrossman@usgs.gov (E.E. Grossman).
}

Consequently, a spatial array of sea-level monitoring stations (tide gauges) recently installed on island shores across the Pacific and satellite altimetry measurements of sea surface topography are beginning to provide local and regional insight into relative sea-level (RSL) change. With adequate time (several decades) these data will provide important information on decadal-scale sealevel behaviour. Repeat Global Positioning System surveys of crustal elevation change at the tide gauge sites will also provide absolute mea- 
surements of any uplift or subsidence trend at each site. Whilst these data will define the present RSL trend, it is important to clarify that RSL change is only one forcing agent of coastal environmental change on the Pacific Islands. This is forced by the combined response of the coastal environment to secular changes in wind and wave climate, coastal currents and sediment transport, sediment budget, anthropogenic influences, and long-term (centennial to millennial) factors such as geological evolution, in addition to RSL changes.

Despite the complex forcing of coastal change, much of the prior research in the Samoan Islands has focused on resolving a complicated history of Holocene relative sea-level change. The initial work by Daly (1924) on Holocene sea-level history included observations of emerged benches and shore platforms on Tutuila Island (Fig. 1). Previous research on Upolu and Savaii Islands (Fig. 1) has described evidence for island emergence (Kear and Wood, 1959; Matsushima et al., 1984; Nunn, 1991, 1998a,b; Sugimura et al., 1988) and submergence (Bloom, 1980; Dickinson and Green, 1998) since the middle Holocene. The conflicting field evidence of Holocene RSL changes in Samoa is similar to that for many $\mathrm{Pa}$ cific Islands (see review in Grossman et al., 1998). The most detailed prior research on Samoan Holocene coastal evolution found evidence of modest coastal progradation $(50-100 \mathrm{~m})$ and island emergence $(\sim 2 \mathrm{~m})$ from reef, and swamp coring and observations of emerged shoreline features such as beachrock and reef flat along southwest Upolu (Sugimura et al., 1988). These results agreed with predictions of emergence $(1-2.5 \mathrm{~m})$ since the middle Holocene, in association with the postglacial hydro-isostatic adjustment (Mitrovica and Peltier, 1991). The evidence for emergence reported by Sugimura et al. (1988), is in apparent contradiction of interpretations of submerged basal peaty muds (Bloom, 1980) and a unit of carbonate cemented sediments overlying Lapita pottery sherds that were retrieved from dredging material at the Mulifanua ferry terminal in northwest Upolu which suggested local island submergence since the middle Holocene (Jennings, 1974). The contrasting Samoan coastal histories imply that coastal evolution has been complex and local influences may be more significant than regional sea-level change. In addition, the application of the Mulifanua site stratigraphy to the interpretation of former sea level has been questioned. The use of Lapita pottery sherds as an indicator of a former shoreline was disputed on the grounds that the Lapita homes may have been built over water and not along the beach, and/or the sherds may have been previously reworked from their original site of deposition (see Nunn, 1991 for more detailed discussion). Recently, Dickinson and Green (1998) reinterpreted the Mulifanua site logs and the RSL of submerged peaty muds from Bloom (1980) as evidence for continuous island subsidence of $1.4 \mathrm{~mm} / \mathrm{yr}$ throughout the middle to late Holocene, which they argued was consistent with the close proximity of Upolu to the seismically active Tonga Trench. Much of this polarised debate on Samoan sea-level history has resulted from the paucity of absolute former sealevel indicators and the absence of a reliable sealevel curve or series of curves. In addition, volcanism and neotectonic displacements around the coastlines of Upolu and Savaii (Kear and Wood, 1959) have complicated the interpretation of coastal change.

Our contribution to the debate was initiated by the perceived need to resolve the long-term coastal evolution over the past few thousand years, as a context for understanding the relative contribution of sea-level, climate and sediment budget changes, and human land practices on coastal stability in the Samoan Islands (formerly Western Samoa). Reconnaissance field surveys were conducted along the Upolu and Savaii coastlines during February 1997. These surveys, together with aerial photo interpretation, were used to review the previously reported field sites and examine the field evidence for RSL emergence and/or submergence, together with associated coastal change. It was apparent to us in the field that the reported field evidence for RSL was unequivocal and that detailed topographic and stratigraphic sections of the coastal plain would be required to elucidate the Holocene coastal evolution and any associated RSL change. Resource and time constraints prevented us from making 


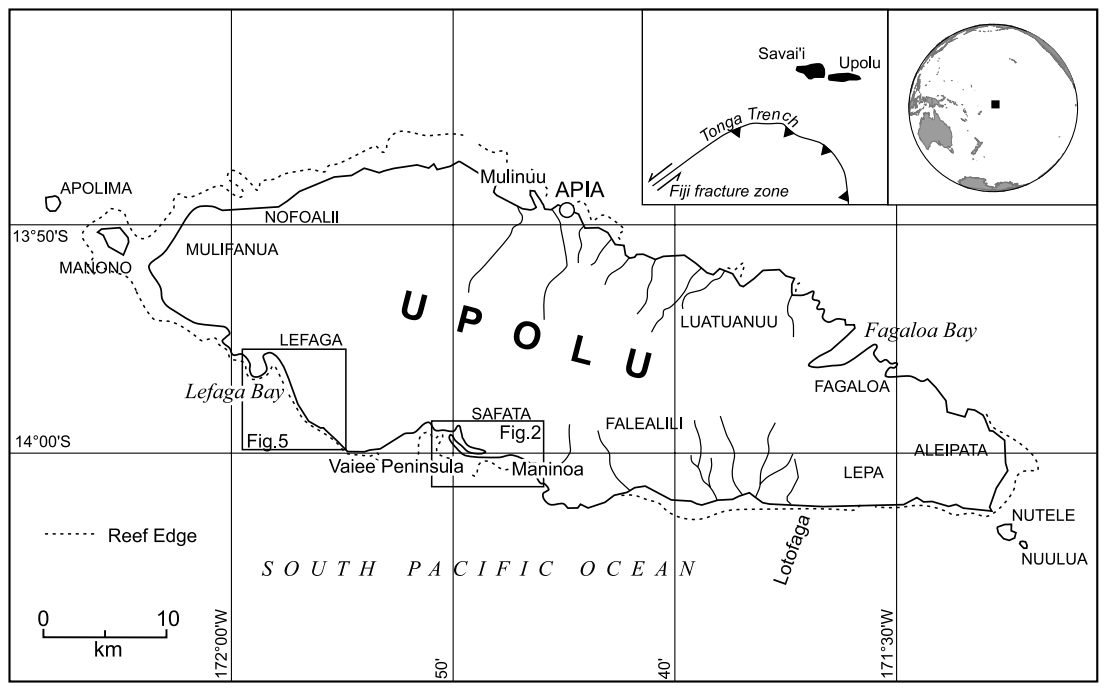

Fig. 1. Map of Upolu showing locations mentioned in the text and the locality of Upolu Island with respect to nearby Savaii Island, the active Tonga Trench subduction zone and Fiji Fracture Zone in the Southwest Pacific.

detailed stratigraphic studies in Savaii. On Upolu, we focussed our investigations along the south coast of Upolu at Lefaga Bay and the Safata coast from Maninoa to Mulivai (Fig. 1). These sites were chosen as type sections of the south Upolu coast and are near the locations of previous investigations by HIPAC (Sugimura et al., 1984), and Tafagamanu (Kear and Wood, 1959), southwest Upolu (Bloom, 1980), Aleipata (Nunn, 1991) and Lotofaga (Davidson, 1969). In addition, both localities have experienced significant coastal recession over recent decades and were considered sensitive to both wave climate, sea-level and sediment budget changes.

\section{Study area}

The Samoan Islands are located in an intraplate tectonic setting within the southwest Pacific Ocean. The two largest islands are Upolu and Savaii. These are high volcanic islands and form part of a linear volcanic chain that stretches from Rose Atoll to Savaii, and are located to the north of the active Tonga Trench subduction zone (Fig. 1). Upolu is elliptical in shape and is $75 \mathrm{~km}$ long and $25 \mathrm{~km}$ wide, with a central ridge of dormant volcanic cones up to $1100 \mathrm{~m}$ in altitude. Savaii is rhomboidal in shape and is $70 \mathrm{~km}$ long and $36 \mathrm{~km}$ wide with a central active volcanic core reaching to $1858 \mathrm{~m}$ altitude (Kear and Wood, 1959). Geophysical surveys and drill cores taken on the reef slopes surrounding Samoa define a series of submarine terraces and drowned reefs interlayered with lava that are indicative of long-term island subsidence throughout the late Quaternary (Daly, 1920, 1924; Keating, 1992; Keating et al., 2000; Richmond, 1992).

The south coast of Upolu receives wave energy from local trade winds, Southern Ocean storms and the passage of tropical cyclones. Significant deepwater wave heights vary from $1.3 \mathrm{~m}$ in January to $2 \mathrm{~m}$ in July and August, with easterly and southeasterly wind waves and southerly swell dominant in the winter. Significant wave height can reach up to $10 \mathrm{~m}$ during severe cyclones, and long period south swells with periods of up to $20 \mathrm{~s}$ produce significant wave heights of up to $4 \mathrm{~m}$ along the south coast (Barstow and Haug, 1994). Wave direction during cyclone events is westerly to southwesterly. Wave direction for trade wind generated waves is typically southeast, although such waves can approach from the west and southwest during El Niño years (Richmond, 1992). Hence, the entire south coast is exposed to high wave energy, which is typically incident 
along the reef front and crest, and along the shore at deep embayments and passages in the fringing reef. Incident and infragravity wave energy propagates to the shore during the highest tides and during storm surges. Wave energy propagating into deep embayments and over the reef flat sets up wave driven longshore currents. The dominant longshore transport is from east to west under the prevailing east to southeast trades (Richmond, 1992). The spring tidal range at Apia, on the northern Upolu coast, is microtidal (between 0.9 and $1.4 \mathrm{~m}$ ).

\section{Methods}

Detailed fieldwork was conducted along the Lefaga Bay and Maninoa to Mulivai coastlines. This included topographic profile surveys of the coast and nearshore reef flat, coring of coastal plains, beach sediments, reef crest and microatoll corals, next to subsurface grab samples of nearshore and reef flat marine carbonate sediments. Topographic surveys were conducted using an automatic level, and the elevations were reduced to mean sea level (MSL) using simultaneous tidal observations relative to the Apia tide gauge, and contain a calculated uncertainty of $\pm 0.20 \mathrm{~m}$ due to estimates of tidal lag after Apia, and differential wind setup between the north and south coasts during the period of observation. Sediment chronologies were obtained by AMS ${ }^{14} \mathrm{C}$ analyses (at the Australian Nuclear Science and Technology Organisation (ANSTO) facility, Sydney, Australia) on samples from cores and surface sampling. Select duplicate samples were submitted for $\mathrm{Th} / \mathrm{U}$ series alpha counting to assess bomb radiocarbon contamination of corals and the local marine reservoir correction applied to marine sample calibration. Cementation histories of beachrock and identification of marine carbonate skeletal constituents were derived from thin section petrology.

Samples submitted for radiometric dating included coral clasts, carbonate sand grains, beachrock cements, and mangrove peat. All coral and carbonate sand samples were selected on the basis of nil diagenetic alteration and were pretreated with ultrasonic washing and acid etching. Sample $\delta^{13} \mathrm{C}$ was measured using mass spectrometry at

Table 1

${ }^{14} \mathrm{C}$ ages of shoreline features from South Upolu Island, Samoa

\begin{tabular}{|c|c|c|c|c|c|}
\hline Laboratory code & Description $^{\mathrm{a}}$ & $\begin{array}{l}\text { Elevation } \\
(\mathrm{m}, \mathrm{msl})\end{array}$ & $\delta^{13} \mathrm{C}$ & ${ }^{14} \mathrm{C} \pm(1 \sigma)^{\mathrm{b}}$ & $\begin{array}{l}\text { Calibrated age ( } 2 \sigma \text { range) } \\
\text { (yr BP) }\end{array}$ \\
\hline \multicolumn{6}{|c|}{ Maninoa, Upolu, Samoa $\left(14^{\circ} 0.05^{\prime} \mathrm{S}, 171^{\circ} 47.05^{\prime} \mathrm{W}\right)$} \\
\hline OZD489 & Porites sp. top of basal shingle & 0.23 & -0.75 & $1200 \pm 70$ & $681(876-559)$ \\
\hline OZD059 & Porites sp. base of basal shingle & 0.18 & -0.27 & $1480 \pm 70$ & $959(1164-789)$ \\
\hline OZD057 & Peat exhumed at shoreline & 0.04 & -28.37 & $260 \pm 60$ & $296(476-252)$ \\
\hline OZDO58 & Porites sp. below peat unit & -0.06 & -0.93 & $3280 \pm 110$ & $3039(3321-2771)$ \\
\hline OZD062 & Coral, in top of lithified spit & 0.39 & -0.01 & $4400 \pm 80$ & $4485(4775-4245)$ \\
\hline OZD060 & Coral, cor-algae clasts, in base of lith. spit & -0.2 & 2.84 & $4320 \pm 100$ & $4392(4699-4067)$ \\
\hline OZD061 & Microatoll (Porites lobata) & -0.1 & -4.48 & modern & modern \\
\hline \multicolumn{6}{|c|}{ Mavaega, Upolu, Samoa $\left(13^{\circ} 57.01^{\prime} \mathrm{S}, 171^{\circ} 57.22^{\prime} \mathrm{W}\right)$} \\
\hline OZD487 & Porites sp., base of landward coastal plain & 0.1 & 0.35 & $1650 \pm 70$ & 1165 (1294-966) \\
\hline OZE057 & S. hystrix, base of landward coastal plain & 0.1 & -1.19 & $1720 \pm 50$ & $1237(1338-1068)$ \\
\hline OZE056 & Porites sp., base of mid-coastal plain & 0.66 & -3.79 & $3070 \pm 60$ & 2767 (2993-2647) \\
\hline OZD486 & Porites sp., base of mid-coastal plain & 0.56 & -1.1 & $3310 \pm 80$ & $3075(3317-2848)$ \\
\hline OZE055 & Porites sp., top landward beachrock berm & 0.19 & 0.72 & $890 \pm 50$ & $477(556-311)$ \\
\hline OZD488 & Porites sp., base landward beachrock berm & 0.07 & 0.13 & $800 \pm 70$ & $414(525-247)$ \\
\hline OZD485 & Porites sp., mid seaward beachrock berm & 0.1 & 0 & $45 \pm 55$ & modern \\
\hline OZE053 & Branching coral, $3 \mathrm{~m}$ seaward of beach toe & -0.97 & -0.23 & $620 \pm 50$ & $248(333-4)$ \\
\hline OZE054 & Branching coral, inner lagoon & -1.14 & -1.62 & $730 \pm 50$ & $303(466-185)$ \\
\hline
\end{tabular}

a Coral samples are clasts unless stated otherwise.

${ }^{b}$ Conventional ${ }^{14} \mathrm{C}$ date. 


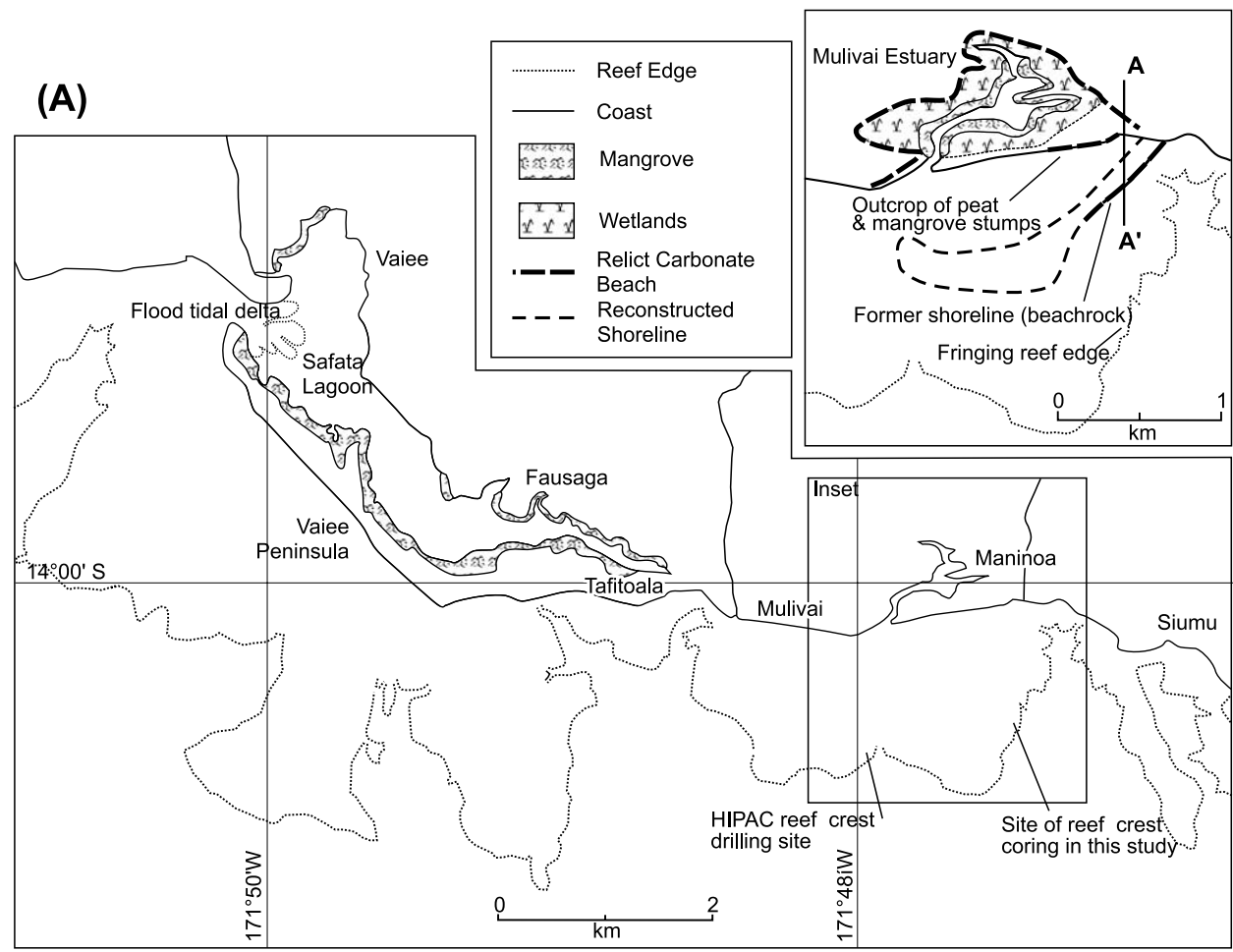

(B)

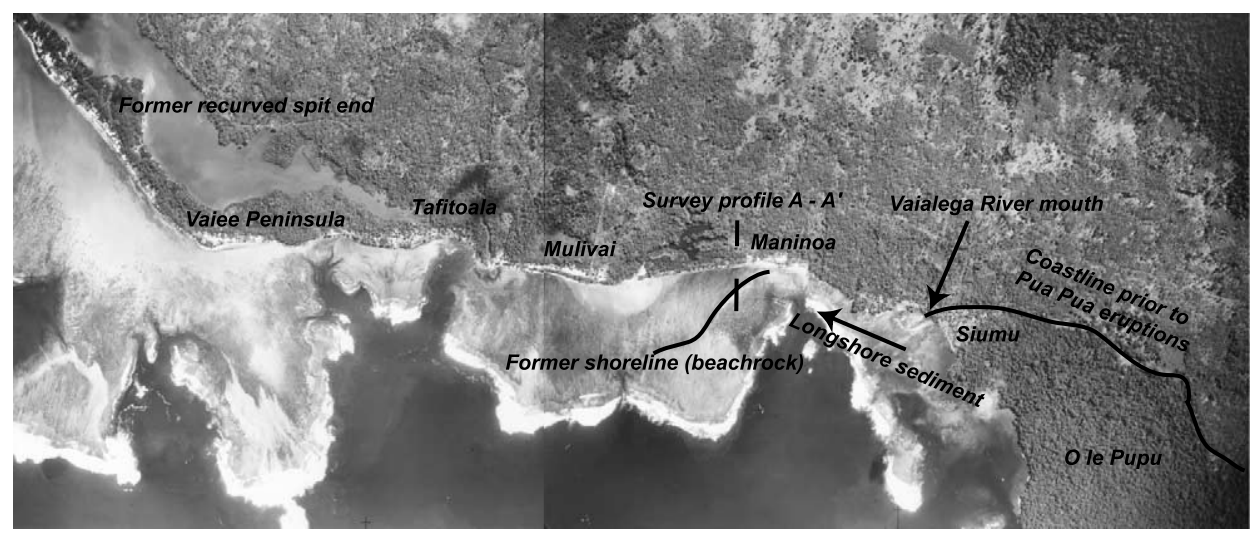

Fig. 2. (A) Map of the coastal morphology of the Upolu Island south coast between Vaiee and Siumu. The location of the survey and coring transect $\mathrm{A}-\mathrm{A}^{\prime}$ at Maninoa is shown in the inset box. The dashed line shows the reconstructed outline of the former Mulivai barrier spit and the former middle Holocene coastline of the Mulivai estuary prior to infilling during the late Holocene. (B) Aerial photograph mosaic of the Siumu to Vaiee coastline, produced from the 1954, 1:21 000-scale New Zealand Aerial Mapping Ltd. frames 2338/21 and 2339/20. 


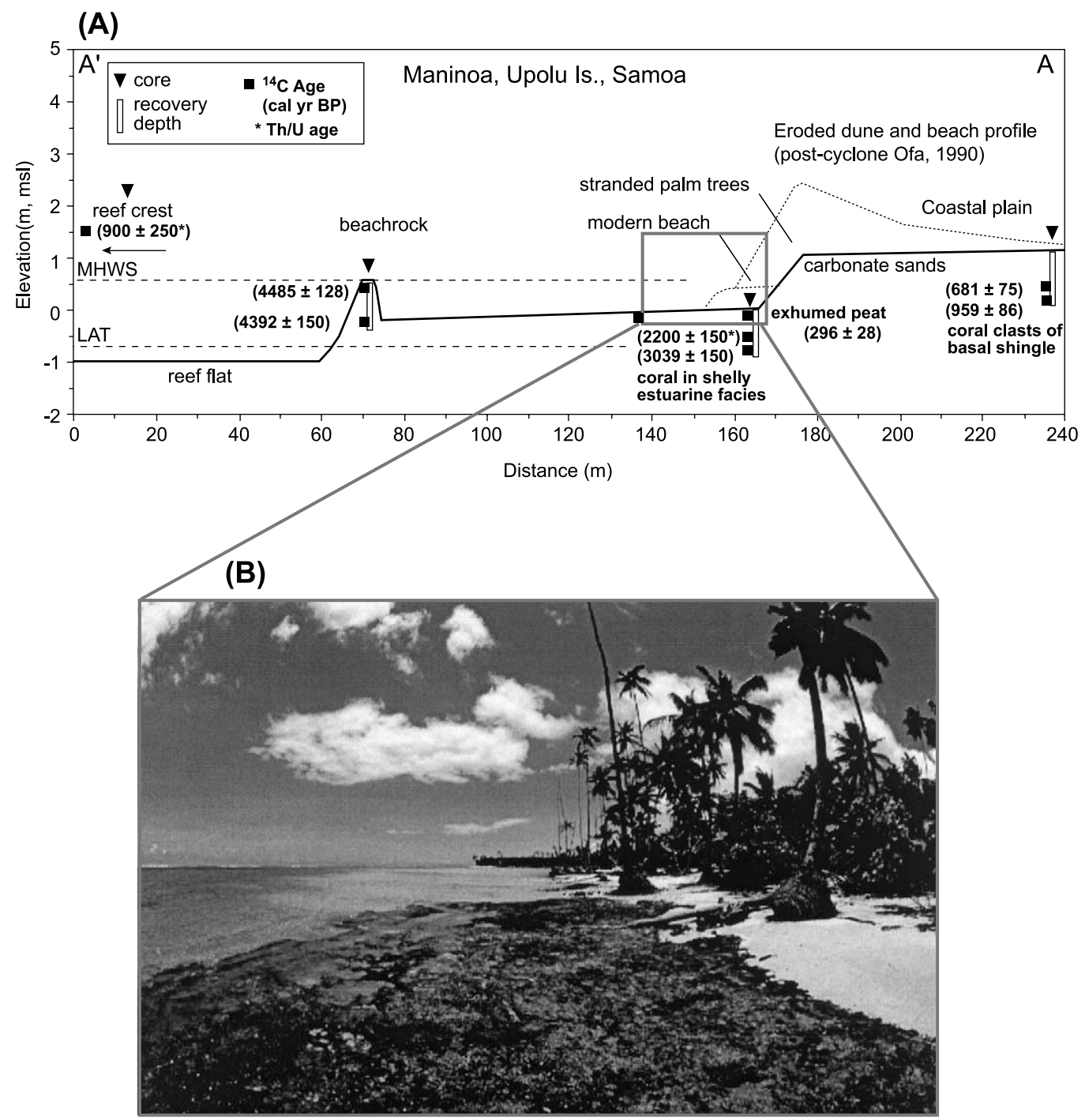

Fig. 3. (A) Topographic profile of Maninoa fringing reef, beach and coastal plain. Also shown are the locations of bore holes and auger holes together with radiocarbon ages of deposits used to constrain the reconstruction of the former coastal configuration. (B) Photograph of recently exhumed peat deposits, now outcropping in the beachface at Maninoa. Photograph taken by the authors in February 1997, during a neap low tide. Note the stranded and undercut palm trees as a result of coastal recession.

the University of Wollongong. Radiocarbon ages were corrected for the regional marine reservoir effect (480 \pm 23 years, after Phelan, 1999) and calibrated using Calib 4.12 (Stuiver and Reimer, 1993). Ages are quoted as calendar ages before AD 1950 with a two standard deviation $(2 \sigma)$ uncertainty (Tables 1 and 2). Previously published uncorrected ${ }^{14} \mathrm{C}$ dates were calibrated following Stuiver et al. (1998).

\section{Results}

\subsection{Coastal morphology and stratigraphy at Maninoa, south coast Upolu Island}

The Maninoa shoreface, like most of the south coast between Lefaga Bay and Lotofaga, is characterised by a fringing reef, dissected in places by freshwater discharge from streamflow, and is 
backed by a low-lying coastal plain (Fig. 2). Barrier beaches and cuspate spits enclose estuarine systems at varying stages of maturity from fully mature infilled swamps and closed mangrove swamps to tidal-dominated estuaries such as Safata Lagoon, Upolu's largest tidal estuary, landward of the $4.2-\mathrm{km}-$ long Vaiee Peninsula. Maninoa lies at the eastern edge of a 1-km-long barrier spit, enclosing the small, relatively mature, Mulivai estuary, that is largely infilled with fringing mangroves and has only an episodic connection to the sea (Fig. 2). The estuary receives freshwater drainage from a groundwater spring (FAO, 1992). Mangroves border the Mulivai estuary and mangrove peat and peaty muds are accumulating within the upper tidal range to Highest Astronomical Tide.

The fringing reef reaches $2 \mathrm{~km}$ in width offshore of Vaiee, while to the east, near Siumu, it is truncated by the Pua Pua lava delta which extends across a presumed palaeoreef flat to its seaward edge (Kear and Wood, 1959). This lava terrain known as the $\mathrm{O}$ le Pupu terminates in deep water and forms an 11-km-long 'ironbound' cliffed coastline (Fig. 2). It is suspected to be of late Holocene age (Kear and Wood, 1959). Maninoa is located midway between the Vaiee Peninsula and the $\mathrm{O}$ le Pupu. This coast has experienced severe beach erosion and coastline recession during the past two decades, leaving coconut palms fallen and abandoned on the fringing reef flat and an arcuate, relict shoreline feature (beachrock) stranded $80 \mathrm{~m}$ offshore within the back reef platform (Fig. 2). This beachrock outcrop parallels the shoreline for over $2 \mathrm{~km}$ and outcrops above Mean Sea Level (MSL) to near the Mean High Water Spring (MHWS) tide elevation, separating a shallow reef flat (1 $\mathrm{m}$ depth) from the primary outer reef flat which ranges $1-3 \mathrm{~m}$ in depth and up to $1.5 \mathrm{~km}$ in width. The reef flat slopes upwards to the reef crest, which becomes exposed during water levels between MLWS and Lowest Astronomical Tide (LAT).

\subsubsection{Maninoa coastal plain}

The Maninoa coastal plain along our study transect (A-A'; Fig. 2) is $100-200 \mathrm{~m}$ wide with minimal relief and elevations $\sim 1.5 \mathrm{~m}$ above MSL. At the modern shoreline the coastal plain is scarped (Fig. 3). The upper $1 \mathrm{~m}$ of the coastal plain is comprised of fine to medium carbonate sands derived of reef skeletal material of which coral, coralline algae and molluscs are primary constituents. Medium to coarse carbonate sand and coral rubble lie under this upper section of fine material at a depth of $1.2 \mathrm{~m}$ in the coastal plain and $60 \mathrm{~m}$ landward of the shoreline. Coral clasts (Porites $s p$.) from this rubble section yield ${ }^{14} \mathrm{C}$ ages of $959 \pm 86$ and $681 \pm 75$ cal yr BP (OZD059 and OZD489) at +0.18 and $+0.23 \mathrm{~m}$ above MSL, respectively (Fig. 3A). The fine to medium surficial sands of the coastal plain grade into medium sands at the shoreline. Recent erosion has exhumed a wave-cut terrace comprised of dense mangrove peat (Fig. 3B) which yielded a date of 296 cal yr BP (OZD057). This peat out-

Table 2

$\mathrm{Th} / \mathrm{U}$ ages of shoreline features from South Upolu Island, Samoa

\begin{tabular}{|c|c|c|c|c|c|c|}
\hline Laboratory code & Description & $\begin{array}{l}\text { Elevation } \\
(\mathrm{m}, \mathrm{msl})\end{array}$ & $\delta^{13} \mathrm{C}$ & ${ }^{234} \mathrm{U}^{238} \mathrm{U}^{\mathrm{a}}$ & $\begin{array}{l}{ }^{230} \mathrm{Th} /{ }^{234} \mathrm{U} \\
(1 \sigma)\end{array}$ & $\begin{array}{l}\text { Th/U Age } \\
\text { (yr BP) }\end{array}$ \\
\hline \multicolumn{7}{|c|}{ Maninoa, Upolu, Samoa $\left(14^{\circ} 0.05^{\prime} \mathrm{S}, 171^{\circ} 47.05^{\prime} \mathrm{W}\right)$} \\
\hline 7381L1 & Porites sp., top of basal shingle & 0.23 & -0.75 & 1.16 & $0.007 \pm 0.001$ & $800 \pm 100$ \\
\hline 7378L1 & Porites sp., base of basal shingle & 0.18 & -0.27 & 1.16 & $0.007 \pm 0.001$ & $800 \pm 100$ \\
\hline 7377L1 & Porites sp., below peat & -0.06 & -0.93 & 1.16 & $0.020 \pm 0.001$ & $2200 \pm 150$ \\
\hline 7379L1 & Microatoll (Porites lobata) & -0.1 & -4.48 & 1.16 & $0.0008 \pm 0.0007$ & $100 \pm 100$ \\
\hline $7380 \mathrm{~L} 1$ & $\begin{array}{l}\text { In situ Porites sp., in limestone } \\
\text { of reef crest pavement }\end{array}$ & -0.3 & -0.91 & 1.17 & $0.008 \pm 0.002$ & $900 \pm 250$ \\
\hline \multicolumn{7}{|c|}{ Mavaega, Upolu, Samoa $\left(13^{\circ} 57.01^{\prime} \mathrm{S}, 171^{\circ} 57.22^{\prime} \mathrm{W}\right)$} \\
\hline $7382 \mathrm{~L} 1$ & Porites sp., base of landward coastal plain & 0.1 & 0.35 & 1.16 & $0.011 \pm 0.001$ & $1200 \pm 150$ \\
\hline
\end{tabular}


crops along $\sim 200 \mathrm{~m}$ of the beach towards Mulivai, at an elevation of 0 to $\sim 0.5 \mathrm{~m}$ above MSL. These peat deposits lie unconformably over a coral-rich rubble and shelly carbonate sand unit yielding ages between $2200 \pm 200 \mathrm{yr}$ BP $(7377 \mathrm{~L} 1)$ and $3039 \pm 150$ cal yr BP (OZD058). The peat outcrop is located less than $100 \mathrm{~m}$ seaward of modern mangrove stands in the Mulivai swamp.

\subsubsection{Beachrock outcrops and fringing reef flat at Maninoa}

The shore-parallel arcuate beachrock outcrop is located $80 \mathrm{~m}$ offshore (Figs. 2 and 4A) and is composed of lithified, seaward dipping, carbonate sands with some layers of fine-grained volcaniclastic sands, and occasional gravel-sized coral clasts. The volcaniclastic sands were most likely transported from the terrestrial environment to the littoral environment by nearby streams during flood events. The beachrock stratigraphy is continuous along the entire 2-km-long outcrop that rests unconformably above the back reef flat. In places, the outcrop reaches $1.5 \mathrm{~m}$ in height above the reef flat to $+0.7 \mathrm{~m}$ above MSL. The mixed volcanic and carbonate grains are lithified by fibrous, acicular, aragonite cements (Fig. 4B) indicating cementation in a high-energy, shallow marine environment (e.g. intertidal section of a beach; Tucker and Wright, 1990). Coral clasts (Porites sp.) from near the base of the cemented spit $(-0.2 \mathrm{~m} \mathrm{MSL})$ dated $4392 \pm 150(\mathrm{OZD} 060) \mathrm{cal}$ yr BP and samples near the top (+0.4 m MSL) dated $4485 \pm 128$ cal yr BP (OZD062). These dates are indicative of sediment supply dating from the middle Holocene and formation of the former beach sometime thereafter.

Along the reef crest $1.0-1.5 \mathrm{~km}$ offshore, living coral cover ranges $10-25 \%$ among a dominantly unconsolidated, cobble-rich wave-planed crest that is exposed during low water spring tides (Fig. 4C). At several locations within the lagoon, coral-rich sands are more $1-2 \mathrm{~m}$ thick and living coral colonies are rare, restricted to isolated massive head corals of Porites that occasionally form microatolls. While coral samples from cores of the microatolls dated modern (ODZ061), the reef crest surface dated $900 \pm 100$ yr BP (ODZ490). The cobble-dominated reef crest reflects high

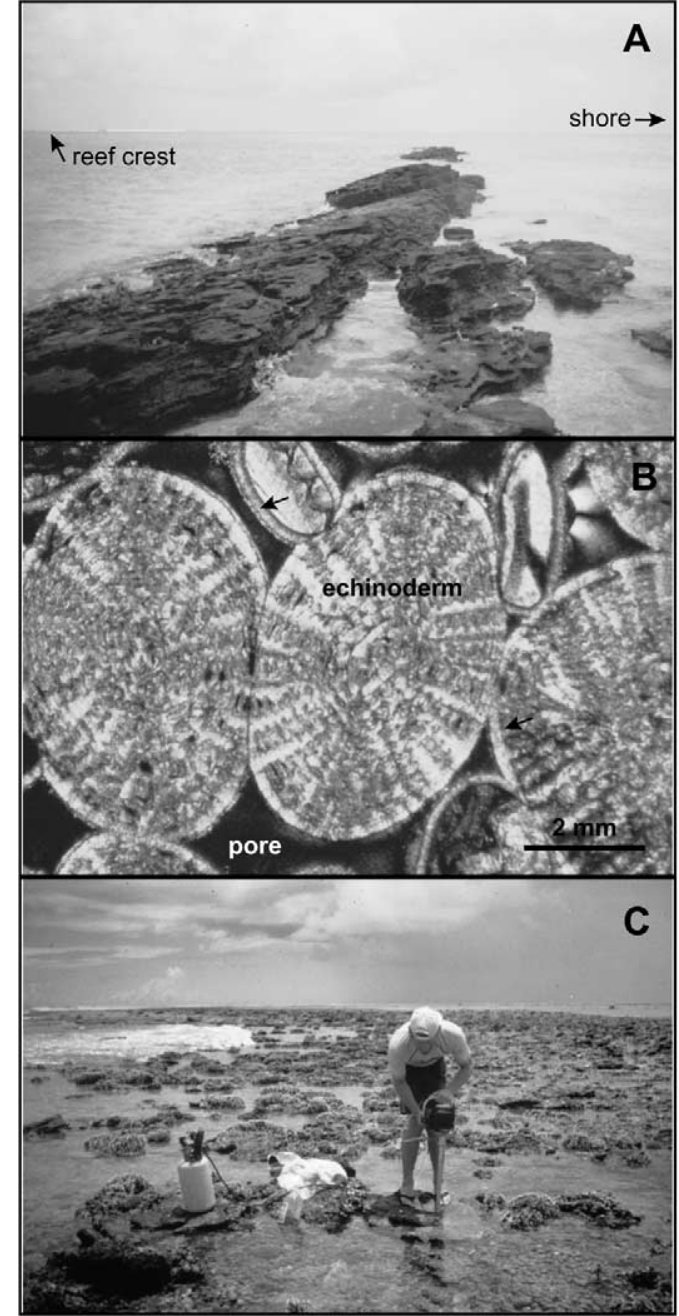

Fig. 4. (A) Lithified relict spit $80 \mathrm{~m}$ offshore of the Maninoa coastal plain. Note the seaward dip of the former beachface deposit. (B) Skeletal fragments of echinoderms, coral, coralline algae, and molluscs cemented by acicular, fibrous aragonite cements (arrows). (C) Modern reef crest emerged at low water spring tide (February 1997). Live coral cover of stoutbranched and encrusting colonies, ranging 20-25\% amidst a limestone pavement. Also shown is the lightweight 1" diameter coring apparatus.

wave energy that reaches this coast annually from south swell. While the coral cover is modest, reaching $20-25 \%$ in portions of the reef flat and crest, little appears to be accreting. Instead, a significant amount of coral-rich sediment appears to 


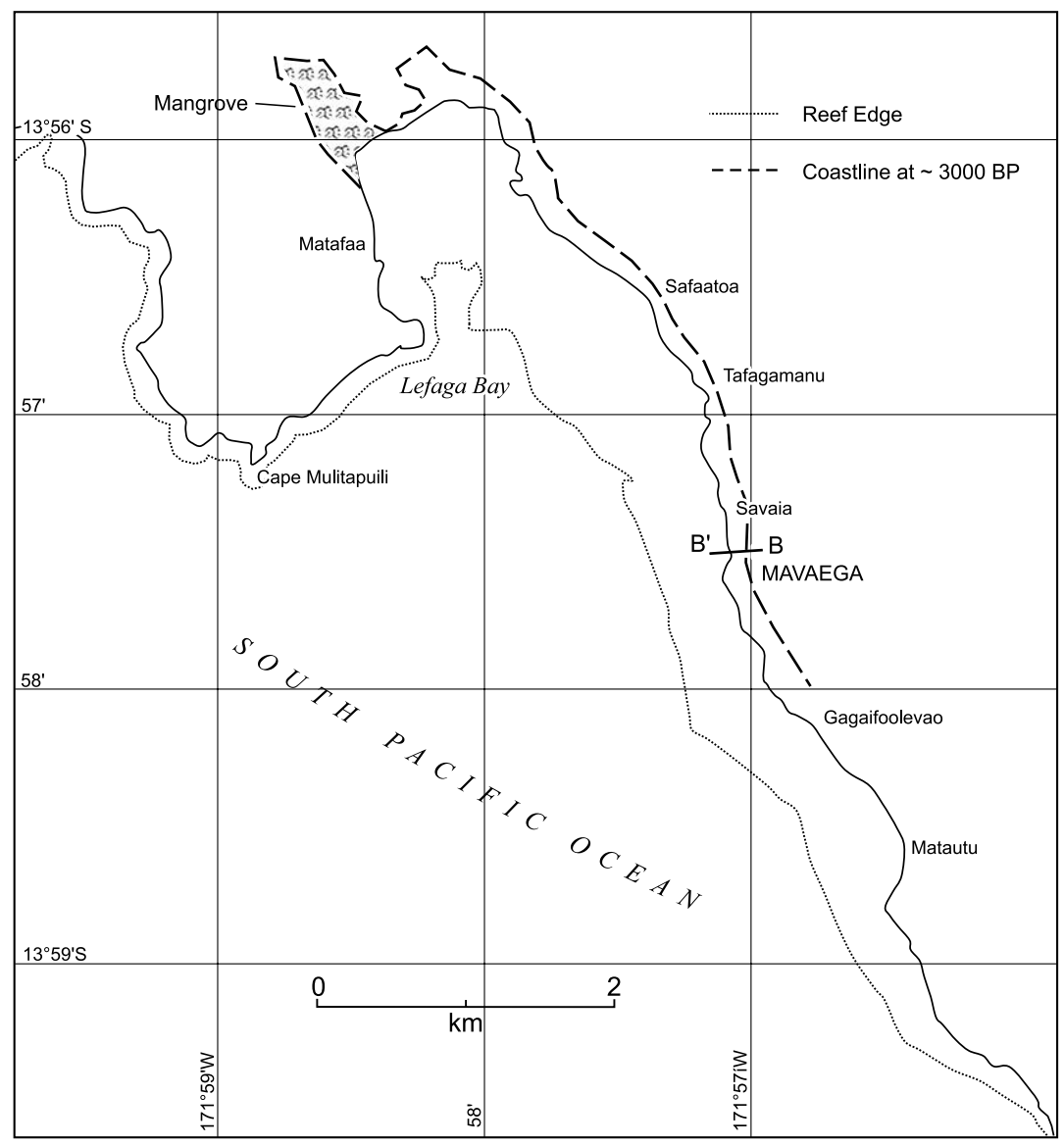

Fig. 5. Map of the coastal morphology of the Upolu Island south coast from Lefaga Bay to Matautu. The survey and coring transect is located at Mavaega. The dashed line marks the location of the former middle to late Holocene coastline at 3000 years BP after Matsushima et al. (1984).

be produced by mechanical abrasion due to incident wave energy at the reef crest and bio-erosion within the lagoon.

\subsection{Coastal stratigraphy at Mavaega, Lefaga Bay, south coast Upolu Island}

Mavaega is located midway between Lefaga Bay and Matautu along the western section of the Upolu south coast. It was selected for our second detailed survey as it is representative of the narrow pocket beach coastline. The fringing reef is up to $800 \mathrm{~m}$ wide in Lefaga Bay but becomes steadily narrower $(200-300 \mathrm{~m})$ toward the southeast (Fig. 5). The shoreline from Matautu east to Tafagamanu faces southwest and is protected from the southeast trades. The obliquity of the coastline ensures a strong littoral current under trade wind conditions. The coast becomes more exposed to the southeast trades from Tafagamanu to Lefaga Bay. Carbonate sand beaches are separated by lava headlands of the Lefaga volcanics, which formed in the early Holocene as pahoehoe flows that may have covered part of an existing reef platform (Kear and Wood, 1959). The previous HIPAC research in this region was concentrated in Lefaga Bay.

The Mavaega coastal plain along our study transect (B-B'; Fig. 5) is relatively narrow $(<500 \mathrm{~m})$. A 3.5 -m-high beach ridge comprising 


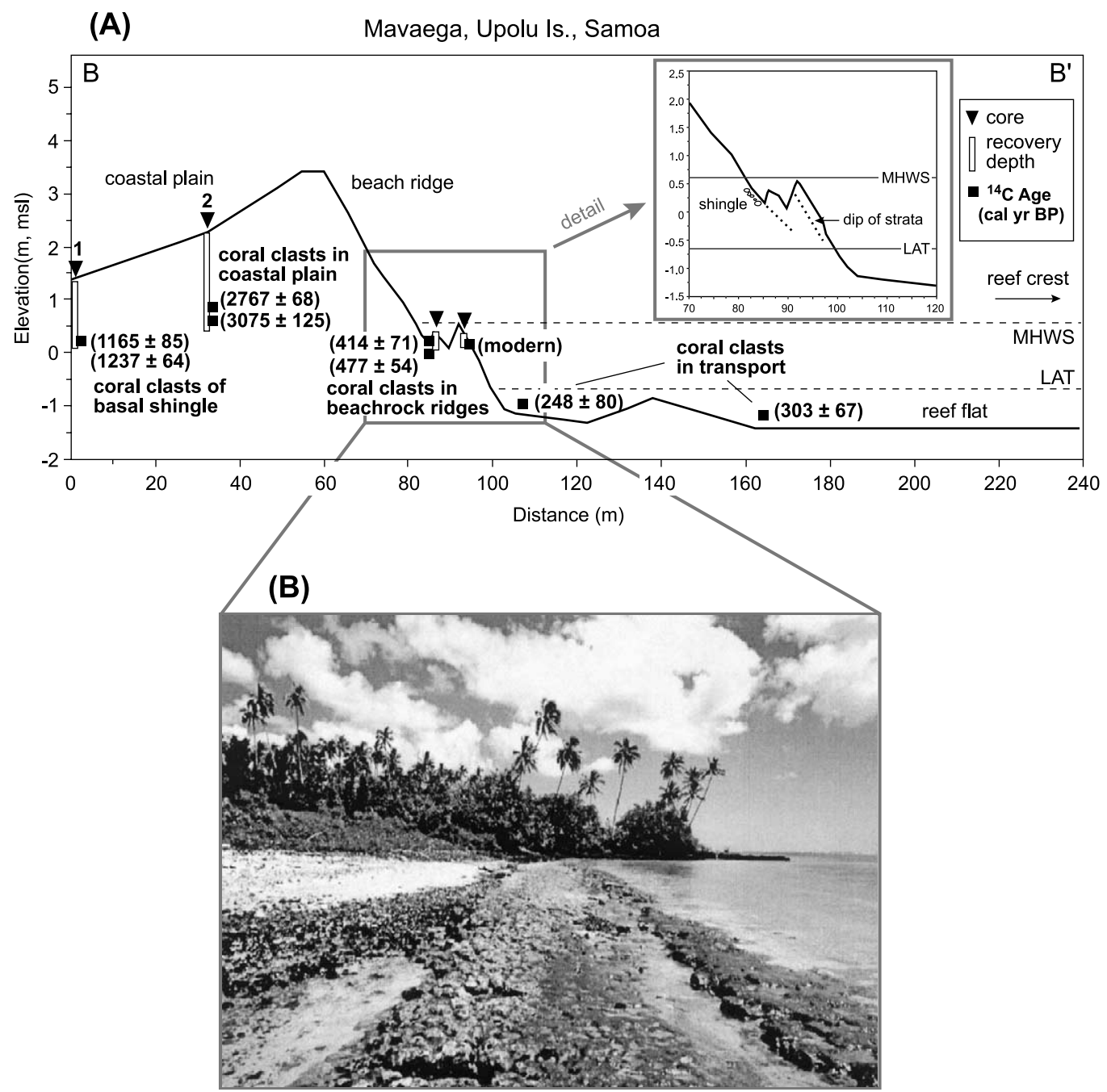

Fig. 6. (A) Topographic profile of Mavaega fringing reef flat, beach and coastal plain. Also shown are the locations of bore holes and auger holes together with radiocarbon ages of deposits used to constrain the reconstruction of the former coastal configuration. The inset box shows the dip of strata within the beachrock and its relationship to the extreme tidal range. (B) Photograph of the Mavaega Beach, a pocket beach with the beachrock cuesta armouring the unconsolidated carbonate sands and frontal dune. Photograph taken by the authors in February 1997, during a spring low tide.

fine to medium grained carbonate sand backs the modern beach (Fig. 6). The back beach is characterised by coral shingle and volcanic boulders, attesting to periodic high wave energy. This coarse sediment is buried beneath beachrock cuesta on the beach face. The beachrock is oriented obliquely towards the updrift coast when compared to the back beach, which attests to different incident wave directions for low and high energy wave climates. The beachrock outcrops between
MHWS and LAT and are comprised of steep, dipping beds of fine to medium carbonate grains that are lithified by fibrous, acicular aragonite cements, indicating cementation within a relatively high-energy shallow marine environment, such as the intertidal portion of a beachface (Fig. 6b).

The coastal plain was augered at three locations along the transect. The sediment profile in a swale (Site 1) located $60 \mathrm{~m}$ inland of the beach ridge comprised a thin veneer of mixed fine-grained vol- 
canic and carbonate sands overlying a $\sim 1.0-\mathrm{m}-$ thick layer of fine to medium carbonate sands. At a depth of -1.25 and $-1.60 \mathrm{~m}$ a layer of pebbles and coral shingle was present beyond which we could not auger. Two coral clasts (Porites sp.) from the basal shingle yielded ${ }^{14} \mathrm{C}$ ages of $1165 \pm 85$ cal yr BP (OZD487) at $+0.1 \mathrm{~m}$ above MSL and $1237 \pm 64$ cal yr BP (OZE057) at $+0.1 \mathrm{~m}$ above MSL (Fig. 6a). At Site 2, a similar stratigraphy was found with $1.1 \mathrm{~m}$ of mixed volcanic and carbonate fine to medium sands, overlying an impenetrable basal layer of coral cobble and shingle. Two coral clasts (Porites sp.) from this shingle yielded ${ }^{14} \mathrm{C}$ ages of $2767 \pm 68$ cal yr BP (OZE056) and 3075 \pm 125 cal yr BP (OZD486) at $+0.66 \mathrm{~m}$ and $+0.56 \mathrm{~m}$ above MSL, respectively. Coral clasts (Porites sp.) from the base of two cores taken from the beachrock yielded ${ }^{14} \mathrm{C}$ ages of $414 \pm 71$ and $477 \pm 54$ cal yr BP (OZD488 and OZE055, respectively). Coral pebbles extracted from the seaward edge of the beachrock yielded a modern radiocarbon age (OZD485). Coral clasts of similar size obtained from surficial sand deposits at the seaward toe of the beachrock berms and within the back reef flat ranged in age from $248 \pm 80$ to $303 \pm 67$ cal yr BP (OZE053 and OZE054, respectively). This unconsolidated material represents sediment that is available for accumulation today, their ages indicate that similar size sediment within the nearshore environment are in transport for $\sim 300 \mathrm{yr} \mathrm{BP}$.

\section{Shoreline evolution}

\subsection{Maninoa, south coast Upolu Island}

The middle Holocene age beachrock was lithified from beach sand deposited within the tidal range of sea level at that time. The beachrock stratigraphy represents beach accretion from episodic inputs of volcaniclastic sediment along with an increasing carbonate sand supply produced from the fringing reef flat and crest. Both sediment types were likely transported by a westward longshore current, driven by the southeast trade winds, with the volcaniclastic sediment probably originating from the Vaialega River system. A modern analog of this depositional history is found at the nearby Vaiee Peninsula. The modern spit forming at Vaiee is oriented parallel to the fringing reef edge and has a recurved end and flood tidal delta, typical of a wave dominated regime (Fig. 2). The small flood tidal delta and recurved end of the spit indicate that sediment is currently transported along the spit from southeast to northwest, under wind-wave driven longshore currents. Its sediment source likely originates from terrigenous output from the major river mouth near Tafitoala at its eastern end, and from carbonate sands produced on the reef. An earlier phase of spit progradation is identified by a relict recurvature of the spit (Fig. 2b). This suggests that the evolution of the Vaiee Peninsula has been episodic throughout the late Holocene.

The age of coral clasts within the beachrock, now $80 \mathrm{~m}$ offshore from the Maninoa beach, implies at least $80 \mathrm{~m}$ of coastline recession and reconfiguration sometime after 4500 cal yr BP. Although surficial unconsolidated sediments from offshore of Maninoa were not dated to establish the range of possible sediment ages that exist offshore, sediment sampled from other littoral segments of Upolu's south coast dated $<300 \mathrm{cal} \mathrm{yr}$ BP indicating that similar size sediment are relatively short-lived in this active littoral system. As a result, carbonate sediments of this size fraction found in deposits in similar high-energy settings are presumed to correspond to within $300 \mathrm{cal} \mathrm{yr}$ of the age of their formation. Over the past 3000 yr the coastal plain inland of Maninoa has aggraded. We interpret the basal layer of coralrich shingle and coarse sands underlying the Maninoa coastal plain as a deposit emplaced episodically by storm wave inundation between $3000 \mathrm{cal}$ yr BP (OZD058) and 700 cal yr BP (OZD489), possibly as recent as $500 \mathrm{cal}$ yr BP, after allowing for residence time within the reef flat environment. The modern coastal plain has aggraded by $\sim 2 \mathrm{~m}$ thickness with carbonate sands and cobbles transported from the beachface and fringing reef flat during wave overwash events since $\sim 1000$ cal yr BP. The deposition of mangrove peat ( $\sim 300$ cal yr BP (OZD057) atop the prior estuarine deposits (2200 cal yr BP, 7377L1) indicates a transition from open marine to a domi- 
nantly freshwater (or brackish) environment in the past few hundred years.

Based on the above stratigraphic relationships we propose a simple model for the development of the Maninoa to Mulivai coast. Our model suggests that the beach sediment along the former coastline was lithified into beachrock by $\sim 4400$ cal yr BP, seaward of an estuary, similar to the modern Vaiee Peninsula and Safata Lagoon system. The prior estuary maintained its configuration at least until $3000 \mathrm{cal}$ yr BP. After this time, progressive slow infilling of the estuary occurred, with water levels sufficient for an open connection to the sea. At or after $\sim 700 \mathrm{cal}$ yr BP a change from estuarine sedimentation to swamp sedimentation occurred enabling rapid mangrove colonisation to take place within the estuary. The modern Mulivai estuary is substantially infilled by sedimentation, has an intermittent connection to the sea and is principally spring fed. This transition from open estuary to closed estuary over the past few hundred years may be linked to a slight lowering of RSL.

The maturation of the Mulivai estuary and/or the period of coastal plain aggradation since $\sim 1000$ cal yr BP may be contemporaneous with the onset of recession along this coastline. However, the Maninoa to Mulivai coastline appears to have experienced more significant coastal reconfiguration than down coast at Vaiee. The influence of the rapid formation of the $\mathrm{O}$ le Pupu cliffed coast on nearshore circulation and longshore transport remains uncertain and could have been an equally important factor to sedimentation and coastal stability. Richmond (1992) recognised that the coastal reconfiguration associated with the emplacement of the $\mathrm{O}$ le Pupu lava terrain over the previous fringing reef flat produced an effective compartmentalisation of the south coast and impeded the dominant westerly longshore transport system immediately to the east of Maninoa. Coupled to the morphological change is a shift in the region's hydrodynamics from a dissipative broad reef flat regime to a steep headland coast proximal to the Maninoa site. It is plausible that both a reduction in sediment supply and an increase in incident wave energy upon the Maninoa-Mulivai coastline led to an erosion regime, eventual shoreline recession, and reduction in the area of the Mulivai estuary. The timing of the Maninoa shoreline recession may be contemporaneous with a renewed sediment supply to Vaiee resulting in the 1-km alongshore extension of the Vaie'e barrier spit from the location of a former recurved spit end as shown in Fig. $2 b$.

\subsection{Mavaega, southwest coast Upolu Island}

The coral shingle and cobble unit found underlying the Mavaega coastal plain represents a coral rubble bank or spit emplaced on the reef flat at ca. 2700-3000 cal yr BP (Fig. 6). The coastal plain has both aggraded and prograded by at least $50 \mathrm{~m}$ since this time from the deposition of overlying coral shingle and fine to medium marine carbonate sands. These sediments have been deposited during high storm surge events. Considerable coastal plain aggradation has occurred from at least $1165 \mathrm{cal}$ yr BP. Storm waves continue to episodically inundate the coastal plain today. The clustered ages of the coral clasts in the beachrock cuesta suggest that they formed during periods of abundant sediment supply in the past 400 $500 \mathrm{cal}$ yr BP. The steep-dipping beds within the beachrock represent the former beachface slope and indicate former shoreline progradation to $\sim 25 \mathrm{~m}$ seaward of the present shoreline position.

In recent decades the overlying unconsolidated sand reserves on the beach have been stripped during storm events, exposing the beachrock and storm rubble foundation. Similar beachrock cuestas are exposed at nearly all of the pocket beaches from Mavaega to Faleseela, in Lefaga Bay and along most of Upolu's coast. All are within the modern tidal range. The slight obliquity between the orientation of the beachrock ridges and the storm beach at Mavaega illustrates sedimentation from the east to west longshore current, and erosion during storm events by incident wave energy from the west to southwest quadrant. The coastline between Lefaga Bay and Matautu suffered extensive erosion during the storm surges and high incident wave energy that accompanied $\mathrm{Cy}$ clone Ofa in 1990 (FAO, 1992). Storm waves inundated the 3.5-4-m coastal plain and exhumed the underlying beachrock. 


\section{Discussion}

\subsection{Holocene environmental change along the south coast of Upolu Island}

The depositional histories and environmental transitions proposed here are in agreement with previous findings of estuary infilling, coastal plain sedimentation and progradation, and reef crest development in Samoa. Matsushima et al. (1984) and Sugimura et al. (1988) reported an upwardfining sequence within the Lefaga Bay swamp that indicated a gradual change from a moderate-energy marine (inner reef flat or lower shore) environment through a low energy estuarine setting to an ultimate closed-swamp environment. Their uncorrected ${ }^{14} \mathrm{C}$ age $\left(1580 \pm 160{ }^{14} \mathrm{C}\right.$ yr BP) of an embedded mollusc shell at the transition from open estuary to closed swamp is equal to a calibrated age of 1145 cal yr BP which is nearly contemporaneous with the same transition observed in the Mulivai estuary near Maninoa. Matsushima et al. (1984) also proposed that between 50 and $100 \mathrm{~m}$ of coastal plain progradation occurred along the Lefaga Bay to Tafagamanu coast (just north of Mavaega) since $\sim 1100$ yr BP (Fig. 5) based on their coastal coring and additional ${ }^{14} \mathrm{C}$ dates reported by Grant-Taylor and Rafter (1962). Grant-Taylor and Rafter (1962) reported an uncorrected ${ }^{14} \mathrm{C}$ date of $1180 \pm 55 \mathrm{yr}$ BP for a coral clast buried at $-1.5 \mathrm{~m}$ in the carbonate-rich coastal plain at Tafagamanu, which corresponds to $710 \mathrm{cal} \mathrm{yr}$ BP. The timing of progradation of the Tafagamanu coastal plain based on the calibrated age is consistent with our results from both Maninoa and Mavaega, illustrating the consistent aggradation history of coastal plains by storm wave overwash events and infilling of prior estuaries and lagoons along the south Upolu coast since 1000-1200 yr BP. This pattern of coastal evolution is consistent with transformation of coastal saltwater lagoons to freshwater-brackish coastal wetlands and swamps on many Pacific Island coasts by 700 cal yr BP (as summarised in Nunn, 1998a, 2000a). The timing of coastal plain aggradation along the Upolu coastline is consistent with the South Pacific archaeological evi- dence for Polynesian coastal settlement abandonment, in response to postulated increases in storm surges after AD 1300 (Nunn and Britton, 2000).

\subsection{Reef crest development and sediment budget along the south coast of Upolu Island during the past millennium}

Sugimura et al. (1988) reported the core logs of reef crest drilling offshore the Lefaga Bay coast. Autochthonous coral dating 1580 uncorrected ${ }^{14} \mathrm{C}$ yr BP (or 1050 cal yr BP) was recovered from $1.5 \mathrm{~m}$ below the reef crest (Sugimura et al., 1988). Matsushima et al. (1984) also drilled the reef crest offshore from Maninoa and Mulivai and found the upper layers dominated by coralline algae and conglomerate carbonate sand. They observed only one layer of autochthonous coral growth at -1.35 to $-1.6 \mathrm{~m}$ depth in a $3-\mathrm{m}$-long core. Our reef crest drilling off Maninoa (Fig. 4c) included six shallow $(\sim 0.3 \mathrm{~m})$ cores of which in situ colonies of Porites sp. and coralline algae comprised a dominant portion of the waveabraded limestone pavement. A Th/ $\mathrm{U}$ age of $900 \pm 200$ yr BP (7380L1) for a Porites sp. coral sampled within the limestone pavement agrees with the HIPAC results that vertical reef accretion on the reef crest has been limited during the past millennium. Coral cover along the reef crest is modest, ranging $15-25 \%$ with some stoutbranched and encrusting corals surviving prolonged tidal exposure and high wave impact (Fig. 4c). While reef crest accretion has been limited since $900 \mathrm{yr} \mathrm{BP}$, coral growth and its subsequent destruction (production of sand) has continued to furnish lagoon, beach and coastal plain sedimentation. Evidence implicating large storm and cyclone wave impacts to the reef crest occurs in the form of large reef blocks and coral boulders strewn across the reef crest and seaward reef platform (Sugimura et al., 1988).

Restricted vertical reef accretion around Upolu is consistent with the widespread evidence for sea-level fall in the southwest Pacific of between $0.25 \mathrm{~m}( \pm 0.1)$ and $0.8 \mathrm{~m}( \pm 0.2)$ sometime between 1150 and $530 \mathrm{cal}$ yr BP (Nunn, 2000b and discussed in Goodwin, 2003). 


\subsection{Implications for interpreting relative sea-level change along the south coast of Upolu Island}

As outlined in Section 1, the previous RSL interpretations for Upolu Island are based on unequivocal indicators of RSL, such as emergent (Sugimura et al., 1988) or submergent (Dickinson and Green, 1998) beachrock, archaeological remnants (Jennings, 1974), coral shingle and sands in the coastal plain (Kear and Wood, 1959; GrantTaylor and Rafter, 1962) which do not indicate a precise relationship to former sea level. Other RSL data have been derived from peat and peaty mud sequences (Bloom, 1980) that are subject to varying rates of autocompaction. Whilst our data on the evolution of the south coast of Upolu also do not provide precise data on former RSL history, they do provide some additional boundary conditions on former RSL, when combined with the previously published studies. Consequently, we comment on the constraints for RSL during the past 5000 years. We have interpreted from the stranded beachrock on the reef flat at Maninoa that a prior carbonate beach formed between $\sim 4000-4500$ cal yr BP within the elevation limits of the modern intertidal range. Between 2200 to 3040 cal yr BP, estuarine sedimentation was occurring within $\pm 1 \mathrm{~m}$ of present MSL in the prior Mulivai estuary, landward of the prior Maninoa beach. The above evidence suggests that at Maninoa relative sea-level changes between $4500 \mathrm{cal}$ yr $\mathrm{BP}$ and the present are small (less than $\pm 1 \mathrm{~m}$ ). Local tectonic movements associated with the late Holocene volcanism and deposition of the $\mathrm{O}$ le Pupu lava terrain within the region are not apparent although we cannot resolve tectonic RSL contributions from our observations. However, the sedimentary record of coastal evolution at Maninoa is not consistent with continuous island subsidence of $7 \mathrm{~m}$ since $5000 \mathrm{cal} \mathrm{yr} \mathrm{BP}$, as suggested by Dickinson and Green (1998) after Bloom (1980). In addition, our observations do not indicate any supporting evidence for island emergence since the middle Holocene as argued by Nunn (1991, 1995). Much of the previously reported evidence for emergence is based on allochthonous coral clasts within the coastal plain. Our observations indicate that these clasts are within the limit of modern storm wave overwash of the beach and barrier complex, and hence cannot be used to infer RSL changes. The most plausible conclusion on the different views of RSL change along the Upolu Island coast is that differential coseismic tectonic movements during the middle to late Holocene may have resulted in a regionally complex rather than uniform RSL history. In fact Jennings (1974) concluded that rapid subsidence of 1-2 m was responsible for the submergence of the Lapita site at Mulifanua on the Upolu west coast. These views are consistent with the evidence for late Holocene volcanism on both Upolu and Savaii islands (Kear and Wood, 1959), terrestrial and submarine faulting, and the evidence for nearby submarine mass-wasting, landslides and seismic activity in the Tonga Trench, $150 \mathrm{~km}$ southwest of the islands (Keating et al., 2000).

However, geodynamic modelling of Holocene sea-level history predicts that postglacial isostatic adjustments should result in a middle Holocene relative sea-level highstand of +1 to $+2.5 \mathrm{~m}$ in Samoa at $4000 \mathrm{yr}$ BP, and a subsequent monotonic RSL fall to present (Mitrovica and Peltier, 1991). Lambeck (2002) argues that the highstand in the Australian and Southwest Pacific regions may have continued until $3000 \mathrm{yr}$ BP and possibly 2000 yr BP due to continued ocean volume increases from Antarctic meltwater. The timing and magnitude of the modelled middle Holocene highstand for Samoa is consistent with field evidence of RSL change elsewhere in the Southwest Pacific (Grossman et al., 1998). Instead, our observations show that the middle Holocene beachrock at Maninoa is not emergent but is located within the modern intertidal range. This constrains the RSL history for this section of the south coast of Upolu Island to describe between 1-2.5 $\mathrm{m}$ of island subsidence since the middle Holocene.

\section{Conclusions}

Dramatic reorientation of the coastline and coastal features including extensive coastal plains, barrier spits and beaches, estuaries and swamps, and fringing reef crests has occurred throughout 
the late Holocene in response to changes in sediment supply brought about by variations in sediment availability and/or coastal hydrodynamics, together with RSL changes, possibly influenced by differential tectonic movements. Sediment availability has largely been furnished by the breakdown of the fringing reef, with a lesser proportion contributed by volcaniclastic fluvial material delivered to the coastal zone. Early and middle Holocene volcanism along the coast enriched the littoral sediment reservoir with clastics and in places such as Siumu realigned the coast and altered the hydrodynamic processes within the nearshore littoral zone. With the cessation of volcanism in the late Holocene, marine carbonate sediments furnished by an active fringing reef and high-wave energy became an increasingly greater component of the littoral sand budget, aiding the formation of extensive coastal plains and barrier spits and the infilling of estuaries. Between about 1000 and $\sim 300$ yr BP expansive coastal plain progradation occurred along the south Upolu coast, presumably fed by high carbonate sediment production as coral growth on the fringing reef platform and crest outpaced accretion, possibly in response to slight RSL lowering. Evidence of episodic high-wave energy events are observed throughout this history in the form of abandoned and realigned barrier spits, overwash deposits on the coastal plain, and emerged reef block boulders. Sustained longshore sediment transport by the prevailing southeast trade winds, however, has apparently controlled the development and distribution of carbonate sand deposits along the entire south Upolu coast since the middle Holocene, prior to a modern period of accelerated erosion. The complexity of coastal evolution on high-volcanic, tropical islands highlights the need for comprehensive surveys of coastal sediment budgets together with the monitoring of RSL changes before appropriate mitigation responses to modern sealevel rise are determined.

\section{Acknowledgements}

The fieldwork was carried out with Samoan logistical assistance coordinated by Dr. Chalapan Kaluwin, South Pacific Regional Environmental Programme (SPREP), and Lameko Talia and Aleni Fepuleai, Apia Observatory. Mr. Aleni Fepuleai provided field assistance and identification of the volcanic stratigraphy. We thank the Coconuts Beach Resort at Maninoa for providing water transport for the nearby lagoon and reef drilling investigations and Dr. Chip Fletcher for travel assistance and valuable discussions. Drs. Ewan Lawson and Henk Heijnis (ANSTO) conducted the AMS radiocarbon and Th/U series measurements, under AINSE grants 97/076, $97 /$ 076R, 98/109 and 98/149R to I.D.G. Mr. Olivier Rey-Lescure drafted some of the figures. We thank Dr. Colin Woodroffe and two anonymous reviewers for their constructive comments which led to a substantial improvement of the paper.

\section{References}

Barstow, S.F., Haug, O., 1994. The Wave Climate of Western Samoa. SOPAC Technical Report 204, South Pacific Applied Geoscience Commission, Suva, Fiji, 35 pp.

Bloom, A.L., 1980. Late Quaternary sea level change on South Pacific coasts: A study in tectonic diversity. In: Morner, N.-A. (Ed.), Earth Rheology, Isostasy, and Eustasy. Wiley, New York, pp. 53-69.

Daly, R.A., 1920. A recent worldwide sinking of ocean-level. Geol. Mag. 57, 246-261.

Daly, R.A., 1924. The geology of American Samoa. Carnegie Inst. Publ. 340, 95-145.

Davidson, J.M., 1969. Excavation of a coastal midden deposit, SU-LO-1 (report 15). In: Green, R.C., Davidson, J.M. (Eds.), Archaeology in Western Samoa, Vol II. Bulletin No. 7, Auckland Institute and Museum, Auckland, pp. 224-252.

Dickinson, W.R., Green, R.C., 1998. Geoarcheological context of Holocene subsidence at the Ferry Berth Lapita site, Mulifanua, Upolu, Samoa. Geoarchaeology 13, 239-263.

FAO, 1992. The Inshore Resources of Upolu, Western Samoa: Coastal Inventory and Fisheries Database. FAO/UNDP SAM/89/002 Field Report 5, Food and Agriculture Organization of the United Nations, Apia, Samoa, 54 pp.

Goodwin, I.D., 2003. Unravelling climatic influences on Late Holocene sea-level variability. In: Mackay, A.W., Battarbee, R., Birks, J., Oldfield, F. (Eds.), Global Change in the Holocene: Approaches to Reconstructing Fine-Resolution Climate Change. Edward Arnold, pp. 406-221.

Grant-Taylor, T.L., Rafter, T.A., 1962. New Zealand radiocarbon age measurements -5 . N. Z. J. Geol. Geophys. 5, 331-359. 
Grossman, E.E., Fletcher, C.F., Richmond, B.M., 1998. The Holocene sea-level highstand in the equatorial Pacific: Analysis of the insular paleosea-level database. Coral Reefs 17, 309-327.

Jennings, J.D., 1974. The Ferry Berth Site, Mulifanua District, Upolu (Report 34). In: Green, R.C., Davidson, J.M. (Eds.), Archaeology in Western Samoa, vol. 2. Auckland Inst. Mus. Bull. 7, Auckland, pp. 176-178.

Kear, D., Wood, B.L., 1959. The geology and hydrology of Western Samoa. New Zealand Geological Survey Bulletin 63, New Zealand Department of Scientific and Industrial Research, 95 pp.

Keating, B.H., 1992. The geology of the Samoan Islands. In: Keating, B.H., Bolton, B.R. (Eds.), Geology and Mineral Resources of the Central Pacific Basin, Circum-Pacific Council for Energy and Mineral Resources Earth Science Series 14, Springer, New York, pp. 127-178.

Keating, B.H., Helsey, C.E., Karogodina, I., 2000. Sonar studies of submarine mass wasting and volcanic structures off Savaii Island, Samoa. Pure Appl. Geophys. 157, 12851313.

Lambeck, K., 2002. Sea level change from Mid Holocene to recent time: An Australian example with global implications. In: Ice Sheets, Sea Level and the Dynamic Earth. Geodynamic Series 29, American Geophysical Union, Washington, DC, pp. 33-50.

Matsushima, Y., Sugimura, A., Berryman, K., Ishii, T., Maeda, Y., Matsumoto, E., Yonekura, N., 1984. Research report of B-party: Holocene sea-level changes in Fiji and Western Samoa. In: Sugimura, A. (Ed.), Sea Level Changes and Tectonics in the Middle Pacific. Report of the HIPAC Project in 1981, 1982 and 1983, Department of Earth Sciences, Kobe University, Nada, Kobe, pp. 137-185.

Mitrovica, J.X., Peltier, W.R., 1991. On postglacial geoid subsidence over the equatorial oceans. J. Geophys. Res. 96, 20053-20071.

Nunn, P.D., 1991. Sea level changes during the last $8000 \mathrm{yr}$ in Fiji, Tonga and Western Samoa: Implications for future coastline development. In: Workshop on Coastal Processes in the South Pacific Island Nations, Lae, Papua New Guin- ea, 1-8 October 1987, SOPAC Technical Bulletin 7, pp. 79 90.

Nunn, P.D., 1995. Holocene sea-level changes in the South and West Pacific. J. Coast. Res. 17, 311-319.

Nunn, P.D., 1998a. Sea-level changes over the past 1,000 yr in the Pacific. J. Coast. Res. 14, 23-30.

Nunn, P.D., 1998b. Pacific Island Landscapes. Institute of Pacific Studies, The University of the South Pacific, Suva, Fiji, 318 pp.

Nunn, P.D., 2000a. Environmental catastrophe in the Pacific Islands around A.D. 1300. Geoarchaeology 15, 715-740.

Nunn, P.D., 2000b. Illuminating sea-level fall around AD $1220-1510$ ( $730-440$ cal yr BP) in the Pacific Islands: Implications for environmental change and cultural transformation. N. Z. Geogr. 56, 46-54.

Nunn, P.D., Britton, J.M.R., 2000. Human-environment relationships in the Pacific Islands around A.D. 1300. Environ. Hist. 7, 3-22.

Phelan, M.B., 1999. A $\Delta \mathrm{R}$ correction value for Samoa from known-age marine shells. Radiocarbon 41, 99-101.

Richmond, B.M., 1992. Coastal geology of Upolu, Western Samoa. In: Keating, B.H., Bolton, B.R. (Eds.), Geology and Mineral Resources of the Central Pacific Basin. Circum-Pacific Council for Energy and Mineral Resources Earth Science Series 14, Springer, New York, pp. 101-125.

Stuiver, M., Reimer, P.J., 1993. Extended 14C database and revised CALIB radiocarbon calibration program. Radiocarbon $35,215-230$.

Stuiver, M., Reimer, P.J., Bard, E., Beck, J.W., Burr, G.S., Hughen, K.A., Kromer, B., Mccormac, F.G., van der Plicht, J., Spurk, M., 1998. INTCAL98 Radiocarbon age calibration 24,000-0 cal BP. Radiocarbon 40, 1041-1083.

Sugimura, A., Maeda, Y., Matsushima, Y., Rodda, P., 1988. Further report on sea level investigations in Western Samoa. In: Yonekura, N. (Ed.), Sea-level changes and tectonics in the middle Pacific. Report of the HIPAC Project in 1986 and 1987, Department of Geography, University of Tokyo, Hongo, Tokyo, pp. 77-84.

Tucker, M.E., Wright, P.V., 1990. Carbonate Sedimentology. Blackwell, Oxford, 482 pp. 